\title{
Urban Space Adaptation in Jurnatan Kampong in the Pandemic Era
}

\author{
Wakhidah Kurniawati ${ }^{1}$, Djoko Suwandono ${ }^{1}$, Nabilla Adhiani ${ }^{1}$ and Khafida Erning Ariyanti ${ }^{1}$ \\ ${ }^{1}$ Diponegoro University, Urban and Regional Planning Department, Semarang, Indonesia
}

\begin{abstract}
COVID-19 pandemic and other global risks such as disaster and climate change force people and cities to cope with adaptation behaviour. Urban kampong and the inhabitants should do adaptive respond to reduce the virus spreading. New normal adaptation is a new behaviour to deal with health protocol and a fast-changing environment. Several kampongs and residents implement New Normal in their adaptation, but the rest organize the adjustment. At the same time, some adjustments do not meet the health protocol requirements due to the crowded kampong challenges to apply physical distancing. Consequently, several kampongs make their peculiar adaptation to fortify their area from pandemic risk and create specific adaptation behaviour. This paper wants to examine the adaptation behaviour in the urban kampong. This research tries to conduct qualitative approaches to seizure the condition in Jurnatan Kampong. The possible result is an actual adaptation behaviour pattern in the urban kampong. Lastly, grounded on the outcome, we will recognize the appropriate action to support peculiar adaptation in an urban kampong in the pandemic era.
\end{abstract}

\section{Background}

The COVID-19 pandemic has changed the global order and affected community activities on all fronts, including people living in densely populated settlements. Currently, $25 \%$ of the world's population (or around 1 billion people) who live in informal settlements are vulnerable to a pandemic. This is because these areas usually do not have adequate essential facilities, are densely populated, and require residents to use shared public facilities [1,2].

Recommended health protocol in preventing transmission of COVID-19 such as washing hands, doing physical distancing, self-quarantine, self-isolation, or community lockdowns are often impossible in informal settlements. In addition, some residents work in the informal sector with unstable incomes, forcing them to ignore suggestions to work at home or maintain physical distance.

Urban kampong, as one representative of informal settlement, is a unique dwelling space in developing countries. As the home of dense and crowded habitation, urban kampong faces challenges in applied health protocol in today's pandemic. Several kampongs practised the internal lockdown for the first time of the pandemic from March until June 2020, but it was temporary. Now, the daily activities back to their habit as before the pandemic. In place of WHO and UN-Habitat mandates on practising new normal adaptation in today era, several kampongs adept with peculiar activities [3]. Those are close the gate in the night hour, limit the outsiders by obligating covid-free letter from them, provide handwash or hand sanitiser 
in crowded points, remind the inhabitants always to use masks and keep physical distancing. However, not everything works well according to health protocols because of the limited space and facilities in the urban kampong. People still do economic activities and communal gatherings on the street alley for their daily needs.

With this informality phenomenon, dense population, and outdoor activity still ongoing during the pandemic, researchers felt the need to determine how responsive adaptation in Jurnatan Kampong, as one representative of urban kampong in Semarang. This adaptive response is part of local inhabitant dealings in fighting the spread of COVID-19 in their area. However, the other response can also be ignoring health protocols in the neighbourhood because of the community's incapability due to economic demands and the absence of space for daily activities except for street alley as an outdoor space.

So this research is considered essential to find out the root causes of the behaviour adaptation patterns of community activity in outdoor areas that existed during this pandemic.

\section{Literature Review}

\subsection{Urban Kampong in Pandemic Era}

Urban kampong is highly vulnerable to the spread of the COVID-19 virus due to its density and high heterogeneity, limited mobility, kinship and impenetrable communal culture [4]. The communal culture of the urban kampong is a challenge and a solution for the adaptation of the kampong to the pandemic [5].

Currently, several studies promote the function of the kampong as the primary defender for public health during a pandemic. Several studies show community survival patterns in the face of the COVID-19 pandemic, such as the lockdown of kampong, increased social awareness, and media virtual support to back kampong activities [4]. Of course, these patterns are not the same in every urban kampong because each kampong has potential, problems, obstacles, challenges, abilities, and uniqueness.

\subsection{Adaptation in Pandemic Era}

Adaptation to a new habit is a recommendation for every person in the world today [6-9]. There are two kinds of adaptation, namely social and cultural adaptation. In public space, to adapt to the new normal tradition, the community usually practices behaviour adaptation. Several studies were carried out in the informal settlement in Dharavi, Mumbai, India and favelas in Brazil. These studies were appropriate out during the 2020 COVID-19 pandemic.

Dharavi is a slum area located in Mumbai, India. This slum area has an area of $2.1 \mathrm{~km} 2$ and is inhabited by 1 million people [10]. At the earlier pandemic in April 2020, the Indian government conducted lockdowns and tests in Dharavi (Trading Economics, 2020). Physical distancing cannot be applied in this place because of the density of occupants and residents. So that community activities continue to run the business as usual. Although the clear health protocol is only wearing masks, strict isolation and quarantine for the infected, this early detection method could reduce up to one-third of the infected population by May 2020.

Favelas in Brazil are also dense settlements that are prone to the spread of the COVID19 virus. About 13 million Brazilians live in favelas, often with more than three people per room and little access to clean water. As a result, this district's physical distancing and hygiene recommendations are almost impossible to implement, and favelas have organized themselves to execute actions within their means [11].

The COVID-19 pandemic shows that various spatial conditions are slow to reduce the spread of the virus. The narrow public circulation space in informal settlements, which accommodate more than one billion people worldwide, makes it impossible for pedestrians to practice physical and social distancing. González and Gongal (2020) [11] propose the Cluster Lane Method to convert circulation networks of any size or complexity into one-way 
networks, allowing physical distances in narrow circulating spaces and limiting face-to-face interactions.

So, behavioural adaptation in the public space in the pandemic era, especially in informal settlements, is wearing masks, strict isolation, quarantine for the infected, preparing the handwash with clean water and soap or hand sanitiser, managing circulation, and physical distancing if possible. Also, avoid the crowded, and work from home.

\section{Methodology}

This paper wants to examine the behaviour adaptation in the Jurnatan Kampong. Therefore, this research will do some stages as below: 1) Identifying general condition of Jurnatan Kampong as one representative urban kampong in Semarang; 2) Identifying and analyzing behaviour adaptation and its adjustment in facing the pandemic in this kampong; 3) Figure out the adaptation pattern in this location.

This study used a qualitative method to capture behaviour adaptation during outdoor activities in a pandemic. Researchers use direct observation and interviews with the community using the activity space in this kampong. These actions were made mainly at the main activity points along the street alley, twice a year, on July 2020 and May 2021.

Jurnatan Kampong in Inspection Road of Semarang River is a linear kampong, creating a linear public space, a street alley or gang. There are three gathering spaces in this linear street alley: workplaces, communal toilets, and culinary spots. Then, the data was captured in those three spaces daily in a week in the morning, noon, and night by direct observation and unstructured interviews with 27 inhabitants.

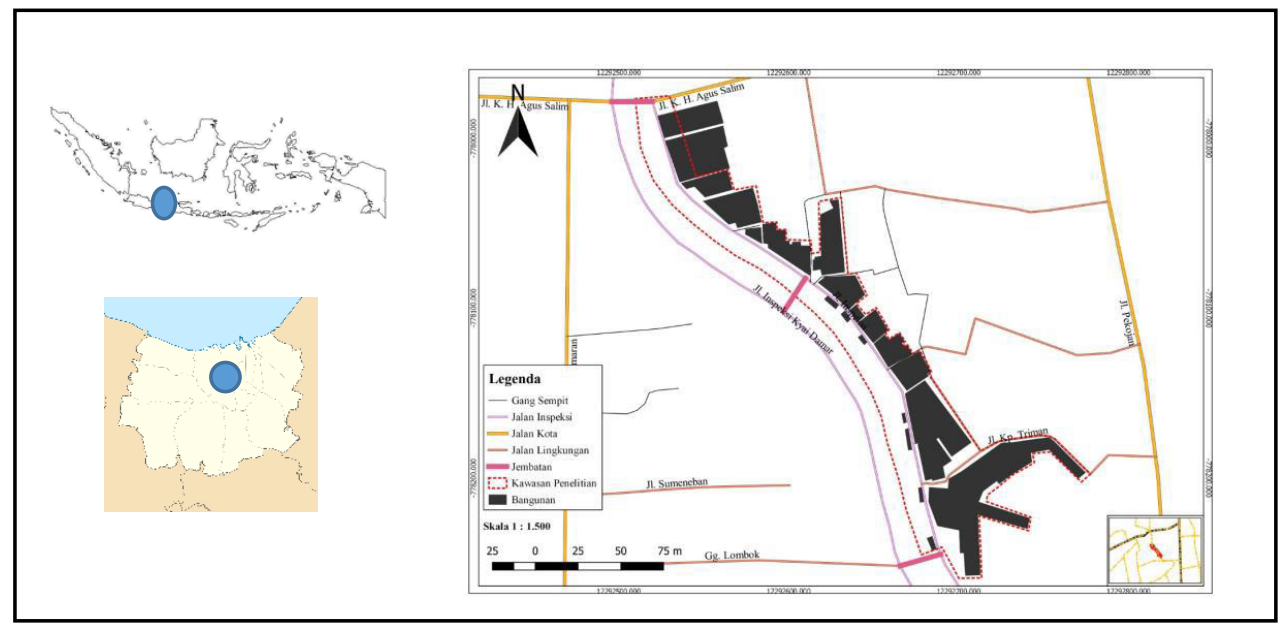

Fig 1. Linear Settlement in Jurnatan Kampong.

Source: Analysis, 2020.

\section{Discussion}

\subsection{General Description of Jurnatan Kampong}

The city of Semarang is one of the Indonesian cities with a high positive number of COVID19. As of February 22, 2021, 30,574 positive cases of COVID-19 were recorded here shows that the city of Semarang accounts for $3 \%$ of Indonesia's national cases. Semarang City, the transportation hub in Java, the entry and exit route for workers from surrounding make the city vulnerable to the spread of the Coronavirus. Jurnatan Kampong, which is situated in urban centres also prone to the spread of the virus. This kampong is densely populated and 
inhabited by residents who work in the informal sector with several boarding houses for shop workers and food stalls for local workers. The intensity of going in and out of people here is relatively high.

Residents are also still actively running their daily activities in the outdoor space. Existing informal economic activities are also carried out along roads used as crossings for outsiders. This riverbank inspection road is prone to spreading the virus because there is no regulation of circulation and application of health protocols, and most residents' activities extend to the road. It is a meeting of place from residents and passers-by. The inspection road, which is also the area's outer space, is the most vulnerable to the spread of the COVID19 virus.

In Jurnatan Kampong, the community's interaction cannot be limited because the main space for activities is the outdoor area. The outdoor space such as street alleys becomes the centre of social, economic activity and expands houses for residents. Previous research by Kurniawati and Dewi (2020) [12] in Jurnatan Kampong, situated on the perimeter of the Semarang River, shows an expansion of activities in the house's external for the economic space. These expansion spaces are in the form of workspaces for shop activities, wood processing, food seller, secondhand goods centres, and aquarium manufacturing workshops, with an area varying from 0.3-1.5 meters located in front of the house, on the side of the street alley, or the banks of the Semarang River.

Apart from being a space for the expansion of economic activities, the outer space in the kampong is also a space for social interaction. The local community uses the outer margin of their house to put personal things, socialize, expand the kitchen activities such as washing clothes and dishes, drying, cooking, etc. Domestic actions taken out of the house have implications of visual clutter in the area and enhance the vulnerability to the spread of the virus because people do not work from home but work outside their homes.

\subsection{Behaviour Adaptation in Pandemic Era}

The community jointly responded to the Large-Scale Social Restrictions (PSSB) in mid-2000 and the Community Activities Limitation (PPKM) in early 2021 but with different responses. They did not lock the area from outsiders to fortify the site from the pandemic due to their strategic location in the urban centre. They applied simple actions outside the area during the pandemic, such as wearing masks and bringing hand sanitiser, but they did not apply strictly inside the location. The direct observation in July 2020 was compared with the condition in May 2021. Both situations show no harsh application of health protocol here.

Table 1. Behavioural Adaptation of Health Protocol.

\begin{tabular}{|c|c|c|}
\hline Health Protocol & Observation on July 2020 & Observation on May 2021 \\
\hline Wearing mask & No compulsory & $\begin{array}{c}\text { No compulsory due to the rare } \\
\text { inhabitants wear the mask }\end{array}$ \\
\hline Provide hand washing facility & $\begin{array}{c}\text { In several points, especially in } \\
\text { the communal toilet }\end{array}$ & $\begin{array}{c}\text { Portable hand wash facility in } \\
\text { culinary spot. }\end{array}$ \\
\hline Physical distancing & No compulsory & $\begin{array}{c}\text { No compulsory due to the } \\
\text { limited space in gathering } \\
\text { spaces }\end{array}$ \\
\hline Work at home & Work outside on street alley & $\begin{array}{c}\text { Work outside on street alley, } \\
\text { especially in workplaces and } \\
\text { culinary spot }\end{array}$ \\
\hline
\end{tabular}




\begin{tabular}{|c|c|c|}
\hline $\begin{array}{c}\text { Managing circulation, limit } \\
\text { access }\end{array}$ & No limitation & $\begin{array}{c}\text { No limitation for the strangers } \\
\text { and passer-by to through the } \\
\text { street alley }\end{array}$ \\
\hline Avoid crowded & No action & $\begin{array}{c}\text { No compulsory due to } \\
\text { inhabitants work and do } \\
\text { activities in a street alley }\end{array}$ \\
\hline Limit night activities & $\begin{array}{c}\text { No action, due to the } \\
\text { commercial area surround } \\
\text { was quiet and no activities at } \\
\text { night }\end{array}$ & $\begin{array}{c}\text { No action due to inhabitants } \\
\text { hold the food stall in the night }\end{array}$ \\
\hline
\end{tabular}

Source: Photos from direct observation, July 2020 and May 2021

From the above table, we can see that there is no significant difference in both observations. Inhabitants do not apply health protocol in outdoor space (street alley). It is related to Lesmana (2020) [4] statement that sometimes urban kampong has its formation. Usually, the community in urban kampong comes from the same root, such as the ethnic, occupation, background, etc. Similar background as immigrants bring awareness that neighbours in kampong are family. Kampong is a big house for inhabitants. So, they do not feel outside the house when they do activities in the street alley. Significantly, the street alley is the house extension, the living room, the family room, and the workspace for the community. So, that is why they do not apply the health protocol strictly. They do not feel worried because they know their neighbours very well.

\subsection{Figure Out the Adaptation and Adjustment in Public Spaces in Jurnatan Kampong}

The most prominent public space in Jurnatan Kampong is the inspection road in the perimeter of Semarang River. The length is approximately 345 metres, and the width is about 2.5-3 metres. See Figure 1. In addition, there are several gathering nodes, such as near the school of Kuncup Melati, in public toilets, in safety points (pos ronda), and some food stalls (warung). In those gathering nodes, the activities are doing a normal situation. No mask, no physical distancing, and no other health protocol applied. So, it can be concluded that there is no behaviour adaptation and adjustment with new habits in this area. People prioritize running their daily activities as before rather than thinking about the pandemic. Based on the interview with some inhabitants, they explained that they have to find a new job selling in kampong to being a docker at a port due to pandemics. Some shops around the Jurnatan kampong are closed. The workers no longer eat and shop in the kampong, so their trade is locked. Then they are forced to find a new job. So, in this case, the inhabitants choose to prioritize adaptation to the economic impact rather than consider the health impact of pandemic. 


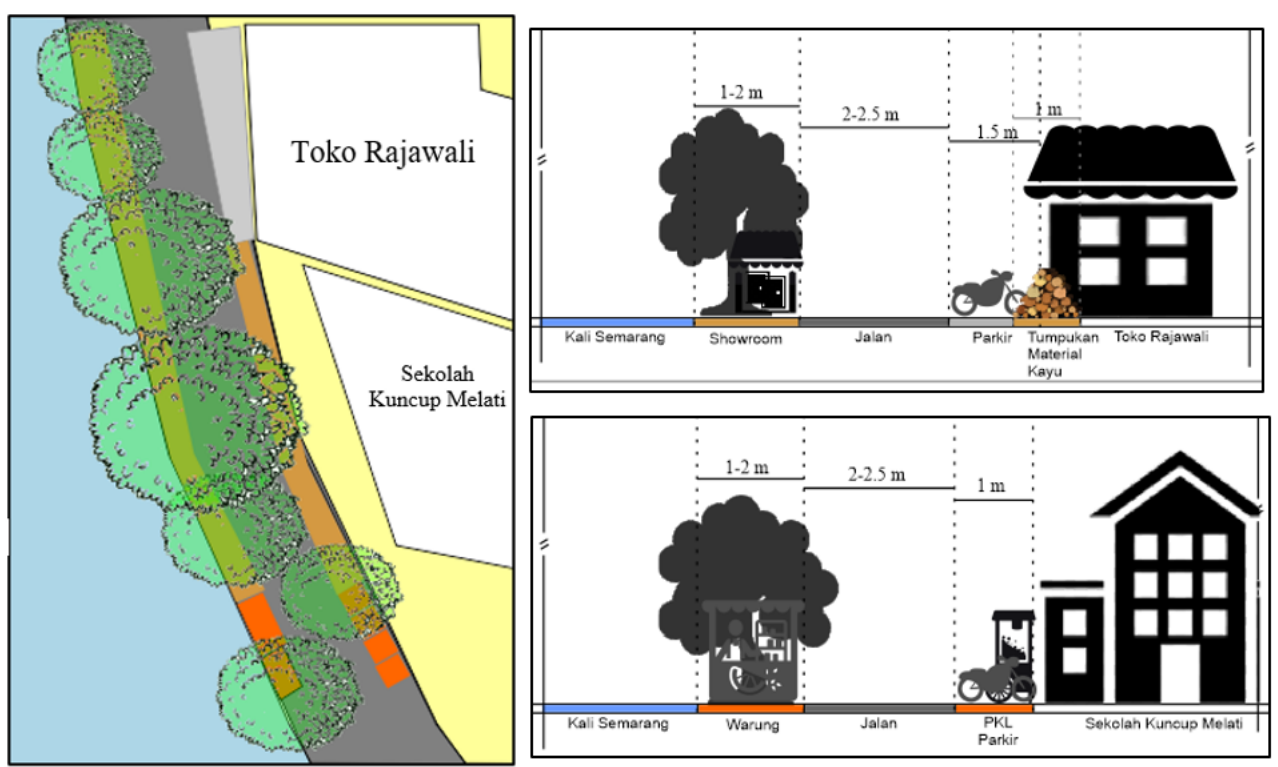

Fig 2. The width of the inspection road (street alley) in Jurnatan Kampong. Source: Analysis, 2020.

\section{Conclusion}

This informality activity was still ongoing in the outdoor area during the pandemic due to the condition. Inhabitants must cope with economic impact and the absence of enough space in the urban kampong. They are forced to ignore health protocols to survive with the economic forces. Therefore, they do not need to adapt and adjust to urban space with the new habit. So, it can be summarized that the peculiar behaviour adaptation here is no action with nowadays pandemic, due to economic impact is more complex than the health impact.

This research was financially supported by The Faculty of Engineering, Diponegoro University, Indonesia, through Strategic Research Grant 2021.

\section{References}

1. United Nations: Economic and Social Council. Progress towards the Sustainable Development Goals: Report of the Secretary-General. (2020).

2. Corburn, J. et al. Slum health: arresting COVID-19 and improving well-being in urban informal settlements. J. urban Heal. 97, 348-357 (2020).

3. GSG Urban Poverty and Housing. Global Responses to COVID-19 in slums and cities. Practices from around the world. (2020).

4. Elviana, E. \& Lesmana, D. Wujud Kebertahanan Kampung Kota Surabaya Pada Masa Pandemi Covid 19. J. Arsit. 11, 1-8 (2021).

5. Widiachristy, L. \& Sutanudjaja, E. Tanggap dan Adaptasi pada Kampung Kota di Era Pandemik. rujak.org https://rujak.org/tanggap-dan-adaptasi-pada-kampung-kota-diera-pandemik/ (2020).

6. The Jakarta Post. Indonesia shifts from 'new normal' to 'adapting to new habits'. https://www.thejakartapost.com/news/2020/07/11/indonesia-shifts-from-new-normalto-adapting-to-new-habits.html (2020).

7. Jane, C. H. Cities Adapting to a New Normal. Urban Solution: Issue 18 94-104 (2021).

8. Gunts, E. Design for Distancing aims to bring life back to public spaces left dormant in lockdown. The Architect's Newspaper https://www.archpaper.com/2020/07/design- 
for-distancing-initiative-aims-to-bring-life-back-to-public-baltimore-spaces (2020).

9. Eltarabily, S. \& Elghezanwy, D. Post-Pandemic Cities-The Impact of COVID-19 on Cities and Urban Design. Archit. Res. 10, 75-84 (2020).

10. Eeshanpriya, M. S. Inside Dharavi: India's largest slum and a major Covid hotspot. https://www.hindustantimes.com/india-news/inside-dharavi-india-s-largest-slum-anda-major-covid-hotspot/story-ZbX5VOngcJImsK9F4ohBvM.html (2020).

11. Gonzalez, J. F. \& Gongal, A. Unidirectional Pedestrian Circulation: Physical Distancing in Informal Settlements. (2020) doi:10.20944/preprints202010.0598.v1.

12. Kurniawati, W. \& Dewi, S. P. Studi Karakteristik Fisik Permukiman Informal Tepi Kali Semarang di Kampung Purwodinatan Semarang. (2020). 